\title{
Five-fold increase in Trypanosoma congolense isolates resistant to diminazene aceturate over a seven-year period in Eastern Zambia
}

\author{
Vincent Delespaux ${ }^{\mathrm{a}, *}$, Hunduma Dinka ${ }^{\mathrm{a}}$, Justin Masumu ${ }^{\mathrm{b}}$, \\ Peter Van den Bossche ${ }^{a, b}$, Stanny Geerts ${ }^{a}$ \\ a Animal Health Department, Institute of Tropical Medicine (Antwerp), Nationalestraat 155, B-2000 Antwerp, Belgium \\ ${ }^{\mathrm{b}}$ Department of Veterinary Tropical Diseases, Faculty of Veterinary Science, University of Pretoria, Private Bag X04, Onderstepoort 0110, South Africa
}

\begin{abstract}
Two groups of Trypanosoma congolense isolates collected from cattle in $1996(n=39)$ and $2003(n=38)$ in the Eastern Province of Zambia were analyzed by $B c l I-P C R-R F L P$ to assess the evolution of diminazene aceturate (DA) resistance over a period of seven years. The results show a significant increase of DA resistance in this relatively short period of time. In 1996, among the 39 isolates, $61.5 \%$ were found sensitive, $12.8 \%$ resistant and $25.7 \%$ had a mixed BclI-PCR-RFLP profile. In 2004, among the 38 isolates, $10.5 \%$ were found sensitive, $63.2 \%$ were resistant and $26.3 \%$ showed a mixed $B c l$ I- $P C R$-RFLP profile. In vivo tests in mice showed that isolates with a sensitive or mixed RFLP profile were sensitive to DA whereas isolates with a resistant RFLP profile were resistant. Since there are no indications that the drug pressure has increased between 1996 and 2003, it is suggested that genetic exchange of resistance genes might explain the increased frequency of resistance to DA.

(C) 2008 Elsevier Ltd. All rights reserved.
\end{abstract}

Keywords: Trypanosoma congolense; Drug resistance; Molecular tools; Diminazene; PCR-RFLP; Zambia

\section{Introduction}

About 9 million $\mathrm{km}^{2}$ of sub-Saharan Africa, representing about one-third of the total land, is infested with tsetse flies (Glossina spp.), which are the main vectors for Trypanosoma (Mattioli et al., 2004). Within this region, some 46-62 million head of cattle and other livestock species are at risk of trypanosomosis, which represents a major constraint on ruminant livestock production (Swallow, 2000). In addition, dozens of human trypanosomosis (sleeping sickness) cases occur in the region annually. Trypanocidal drug resistance (TDR) has become a worrying burden in sub-Saharan Africa and was reported in 17 countries (Delespaux et al., 2008). Although TDR is reported widely (mainly case reports, plus a few area-wide studies), no information is available on the temporal development of resistance in trypanosomes. Indeed, the ease with which TDR spreads in the field remains an open question. This is mainly due to the logistical difficulties and

\footnotetext{
* Corresponding author. Tel.: +32 324763 90; fax: +32 32476268 .

E-mail address: vdelespaux@ @itg.be (V. Delespaux).
}

high costs of longitudinal surveys in a specific site where trypanocidal drugs are used. Furthermore, the in vivo testing of a large number of field isolates for drug sensitivity requires an even larger number of laboratory animals.

The availability of a reliable and sensitive molecular tool that allows the rapid screening for diminazene aceturate (DA) resistance (Delespaux et al., 2006) and the availability of a large number of $T$. congolense strains isolated from cattle in 1996 and 2003 in the same geographic area of Eastern Zambia made it possible to determine the spread of DA resistance in a geographically confined area during this period.

\section{Materials and methods}

\subsection{Study area}

All trypanosome isolates were collected from cattle kept in the Petauke and Katete Districts of the Eastern Province of Zambia. They were collected at 19 sampling sites scattered over the area. Details of each of the isolates are presented in Table 1. The study area is infested with tsetse flies of the 
Table 1

Codes and individual results of the BclI-PCR-RFLP of the 77 isolates of the study.

\begin{tabular}{|c|c|c|c|c|c|}
\hline Code & RFLP profile & Sampling & Code & RFLP profile & Sampling \\
\hline $\mathrm{TRT}^{\mathrm{a}}$ & Sensitive & 1996 & Chipopela324C1 ${ }^{\text {b }}$ & Sensitive & 2003 \\
\hline TRT10 $0^{\mathrm{a}}$ & Sensitive & 1996 & Chipopela38 & Sensitive & 2003 \\
\hline TRT11 $^{\mathrm{a}}$ & Sensitive & 1996 & Chitawe162 & Sensitive & 2003 \\
\hline $\mathrm{TRT}_{12}{ }^{\mathrm{a}}$ & Sensitive & 1996 & Chitawe 172 & Sensitive & 2003 \\
\hline TRT13 & Sensitive & 1996 & Alick326C $1^{\mathrm{b}}$ & Resistant & 2003 \\
\hline TRT20a & Sensitive & 1996 & Alick339C6 ${ }^{\text {b }}$ & Resistant & 2003 \\
\hline TRT29 & Sensitive & 1996 & Alick355 & Resistant & 2003 \\
\hline TRT31 $^{\mathrm{a}}$ & Sensitive & 1996 & Alick589 & Resistant & 2003 \\
\hline TRT35 & Sensitive & 1996 & Alick69 & Resistant & 2003 \\
\hline TRT37 & Sensitive & 1996 & Alick91 & Resistant & 2003 \\
\hline TRT38 ${ }^{\mathrm{a}}$ & Sensitive & 1996 & Alick92 & Resistant & 2003 \\
\hline TRT39 & Sensitive & 1996 & Alick95C $1^{\text {b }}$ & Resistant & 2003 \\
\hline TRT40a & Sensitive & 1996 & Chipopela313 & Resistant & 2003 \\
\hline $\mathrm{TRT}_{4} 2^{\mathrm{a}}$ & Sensitive & 1996 & Chipopela37 & Resistant & 2003 \\
\hline $\mathrm{TRT}_{4} 3^{\mathrm{a}}$ & Sensitive & 1996 & Chitawe163 & Resistant & 2003 \\
\hline TRT44 $^{\mathrm{a}}$ & Sensitive & 1996 & Chitawe556 & Resistant & 2003 \\
\hline $\mathrm{TRT}_{4} 5^{\mathrm{a}}$ & Sensitive & 1996 & Kapeya27 & Resistant & 2003 \\
\hline${\text { TRT } 46^{\mathrm{a}}}$ & Sensitive & 1996 & Kapeya272 & Resistant & 2003 \\
\hline TRT47 $^{\mathrm{a}}$ & Sensitive & 1996 & Кареуа357 & Resistant & 2003 \\
\hline TRT5 $^{\mathrm{a}}$ & Sensitive & 1996 & Kasanda & Resistant & 2003 \\
\hline TRT54 $^{\mathrm{a}}$ & Sensitive & 1996 & Kasanda1 & Resistant & 2003 \\
\hline TRT56 $^{\mathrm{a}}$ & Sensitive & 1996 & Kasanda20 & Resistant & 2003 \\
\hline TRT57 $^{\mathrm{a}}$ & Sensitive & 1996 & Kasanda22 & Resistant & 2003 \\
\hline TRT8 $^{\mathrm{a}}$ & Sensitive & 1996 & Katepela1081 & Resistant & 2003 \\
\hline $\mathrm{TRT}^{2}$ & Resistant & 1996 & Mphita4018 & Resistant & 2003 \\
\hline TRT2 $21^{\mathrm{d}}$ & Resistant & 1996 & MsoroM19 & Resistant & 2003 \\
\hline TRT24 & Resistant & 1996 & MsoroM7 & Resistant & 2003 \\
\hline TRT49 & Resistant & 1996 & Seya147 & Resistant & 2003 \\
\hline TRT61 & Resistant & 1996 & Alick351 & Mixed & 2003 \\
\hline $\mathrm{J} 4 \mathrm{~J} 4$ & Mixed & 1996 & Kapeya116 & Mixed & 2003 \\
\hline TRT15 & Mixed & 1996 & Kapeya12 & Mixed & 2003 \\
\hline TRT16 & Mixed & 1996 & Lombo3020 & Mixed & 2003 \\
\hline TRT17C $1^{b, a}$ & Mixed & 1996 & Seya129 & Mixed & 2003 \\
\hline TRT25 & Mixed & 1996 & Seya148 & Mixed & 2003 \\
\hline TRT3 $^{\mathrm{a}}$ & Mixed & 1996 & Seya389 & Mixed & 2003 \\
\hline TRT32 & Mixed & 1996 & Yobo2007 & Mixed & 2003 \\
\hline TRT33 & Mixed & 1996 & Yobo2028 & Mixed & 2003 \\
\hline TRT48 ${ }^{\mathrm{a}}$ & Mixed & 1996 & Yobo2038 & Mixed & 2003 \\
\hline TRT51 & Mixed & 1996 & & & \\
\hline
\end{tabular}

a Tested in mice: more than $80 \%$ relapses at $1 \mathrm{mg} / \mathrm{kg}$ DA, less than $20 \%$ relapses at $20 \mathrm{mg} / \mathrm{kg} \mathrm{DA}, 0 \%$ relapses at $40 \mathrm{mg} / \mathrm{kg}$.

b Cloned trypanosomes.

c Tested in mice: more than $20 \%$ relapses at $20 \mathrm{mg} / \mathrm{kg}$.

d Tested in mice: less than $20 \%$ relapses at $20 \mathrm{mg} / \mathrm{kg}$, more than $20 \%$ relapses at $5 \mathrm{mg} / \mathrm{kg}$.

species Glossina morsitans morsitans that takes the majority of its bloodmeals from cattle (Van den Bossche and Staak, 1997). Trypanosoma congolense is the dominating trypanosome species (Simukoko et al., 2007). The prevalence of trypanosomosis in cattle is about $30 \%$ and the disease is controlled using trypanocidal drugs, mainly diminazene aceturate (Van den Bossche et al., 2000). In 1996, the prevalence of DA and ISM resistance in the area was evaluated by in vivo tests to be $11.3 \%$ and $34 \%$ respectively (Sinyangwe et al., 2004).

\subsection{Trypanosome isolates}

Two groups of $T$. congolense savannah type isolates were used in this study. The first group $(n=39)$ consisted of isolates collected in 1996 (Sinyangwe et al., 2004), the isolates from the second group $(n=38)$ were collected in 2003 (Masumu et al., 2006).

Trypanosomes were isolated by intraperitoneal injection of $0.5 \mathrm{ml}$ of blood of cattle, found positive for T. congolense using the buffy coat technique (Murray et al., 1977), into mice aged 5-8 weeks and weighing on average $30 \mathrm{~g}$ each. After the parasitaemia had reached a minimum of 7.1 on the Herbert and Lumsden (1976) scale, mice were euthanized and stabilates were prepared using $25 \%$ of a DMSO (20\%) solution as a cryopreservative for long-term storage in liquid nitrogen.

Five of those isolates (TRT17C1, Alick95C1, Alick 324C1, Alick326C1, Alick339C6) were cloned (Smith et al., 1982) to compare the BclI-PCR-RFLP profiles of isolates 
(possible mixture of sensitive and resistant trypanosomes) and clonal populations.

\subsection{Sensitivity testing in mice}

For each isolate, $5 \times 10^{5}$ trypanosomes were inoculated into 20 adult OF1 mice weighing on average $30 \mathrm{~g}$ each. Twenty-four hours after infection, each of the 4 groups of 5 mice was treated intraperitoneally with $0.2 \mathrm{ml}$ of a DA solution at the following doses: $1.0 \mathrm{mg} / \mathrm{kg}, 20 \mathrm{mg} / \mathrm{kg}, 40 \mathrm{mg} / \mathrm{kg}$ for group 1, 2 and 3 respectively. The fourth group was injected with water as a no-treatment control. Following treatment, wet films of tail blood was monitored twice weekly for 60 days for the presence of trypanosomes. For the TRT2 and TRT21 isolates, the experiment was repeated following the same procedure but with a no-treatment control group and a treated group at a dose of $5.0 \mathrm{mg} / \mathrm{kg}$. An isolate was considered as resistant to a specific dose (i.e. 1, 5, 20 or $40 \mathrm{mg} / \mathrm{kg}$ ) when more than $20 \%$ of the mice relapsed (Eisler et al., 2001).

\subsection{DNA extraction}

The cryostabilates of trypanosomes were reactivated by intraperitoneal injection in mice. At the first peak of parasitaemia, the mice were euthanized and the blood collected with anticoagulant. The DNA was then extracted using a routine phenol-chloroform-isoamyl alcohol method (Sambrook et al., 1989). To confirm that the $T$. congolense strains belonged to the Savannah subgroup, the PCR-restriction fragment length polymorphism (PCR-RFLP) technique was used on the small subunit of the ribosomal DNA (Ssu-rDNA) (Geysen et al., 2003; Delespaux et al., 2003).

\subsection{DNA amplification}

Standard PCR amplifications were carried out in $25 \mu \mathrm{l}$ reaction mixtures containing $5 \mu \mathrm{l}$ DNA sample (at $10 \mathrm{ng} / \mu \mathrm{l}$ in the case of reference DNA samples), $50 \mathrm{mM} \mathrm{KCl}, 10 \mathrm{mM}$ Tris- $\mathrm{HCl}$ (pH 8.3), $1.5 \mathrm{mM} \mathrm{MgCl}_{2}, 200 \mu \mathrm{M}$ of each dNTP, $20 \mathrm{pmol}$ of each primer and $0.5 \mathrm{U}$ Taq polymerase enzyme (Goldstar, Eurogentec). The reaction mixture was overlaid with $50 \mu$ l fine neutral mineral oil (Sigma) and placed on a heating block of a programmable thermocycler (PTC-100 TM, M.J. Research Inc.). After a denaturation step of 4 min at $94{ }^{\circ} \mathrm{C}$, each of the 40 cycles consisted of $30 \mathrm{~s}$ at $94{ }^{\circ} \mathrm{C}, 45 \mathrm{~s}$ at $59^{\circ} \mathrm{C}$ and $45 \mathrm{~s}$ at $72{ }^{\circ} \mathrm{C}$. A $5 \mu \mathrm{l}$ volume of each sample was electrophoresed in a $2 \%$ agarose gel for $30 \mathrm{~min}(100 \mathrm{~V})$ and stained with ethidium bromide for $30 \mathrm{~min}$.

\subsection{Primers}

Primers used for the diagnosis of DA resistance in $T$. congolense were described by Delespaux et al. (2006). The forward primer Ade2F sequence was ATAATCAAAGCTGCCATGGATGAAG, the reverse primer Ade2R sequence being GATGACTAACAATATGCGGGCAAAG.

\subsection{BclI-PCR-RFLP}

The $B c l$ I-PCR-RFLP reactions for the detection of resistance to DA were performed as described by Delespaux et al. (2006).

\subsection{Statistical analysis}

The Fischer exact test (Weisstein, 2008) was used to analyse the two categorical variables: drug sensitivity with three observed categories (sensitive, resistant, mixed) and time of sampling with two observed years (1996 and 2003).

\section{Results and discussion}

Fig. 1 shows the three different BclI-PCR-RFLP profiles which were obtained, i.e. sensitive, resistant and mixed. Mixed profiles may be the result of either a mixture of trypanosomes consisting of homozygous sensitive, homozygous resistant and/or heterozygous subpopulations, or from a whole parasite population that is heterozygous for the point mutation in the TcoATl gene conferring DA-resistance (Delespaux et al., 2006). To confirm the hypothesis that heterozygous strains were present in the trypanosome population and have a mixed RFLP profile, the profile of five cloned strains was compared. The BclI-PCR-RFLP showed that the cloned strains Alick95C1, Alick326C1 and Alick339C6 presented resistant RFLP profiles and can thus be classified as homozygous resistant. The cloned strain Chipopela324C1, on the other hand, presented a sensitive RFLP profile and can thus be classified as homozygous sensitive. Finally, the cloned strain TRT17C1 presented a mixed RFLP profile and can thus be considered as heterozygous for the $\mathrm{G}$ to $\mathrm{A}$ point mutation in the P2-type purine transporter gene TcoAT1,
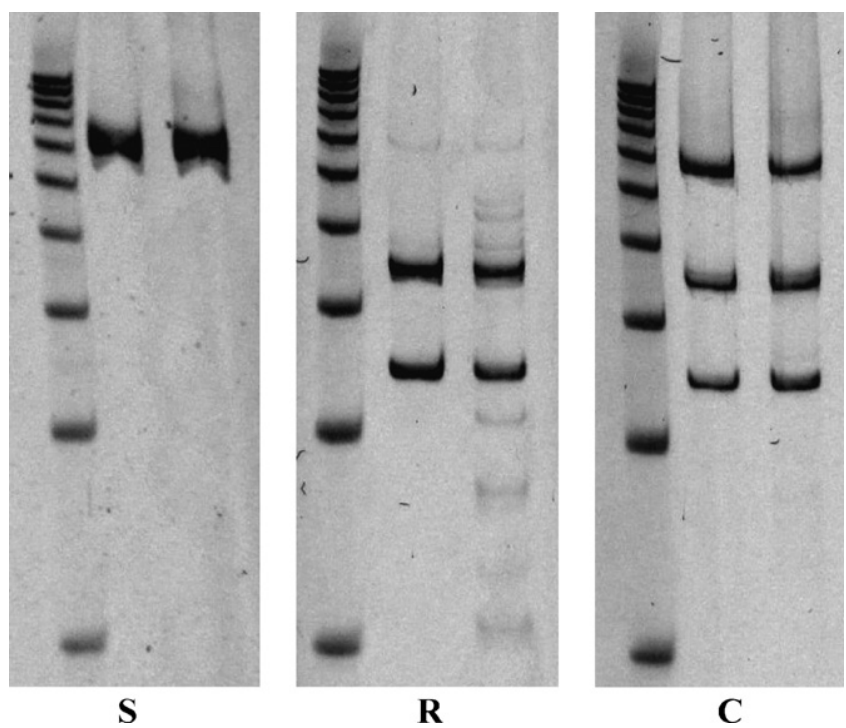

Fig. 1. Example of the BclI-PCR-RFLP sensitive (S), resistant (R) and mixed (M) profiles. 
Table 2

Number of T. congolense isolates collected in the Eastern Province of Zambia in 1996 and 2003 and presenting a sensitive, resistant or mixed BclI-PCR-RFLP profile.

\begin{tabular}{|c|c|c|c|c|}
\hline \multirow[t]{2}{*}{ Year of isolation } & \multicolumn{3}{|c|}{ Number of strains with $B c l I-P C R-R F L P$ profile } & \multirow[t]{2}{*}{ Total } \\
\hline & Sensitive (\%) & Resistant (\%) & Mixed (\%) & \\
\hline 1996 & $24(61.5)$ & $5(12.8)$ & $10(25.7)$ & $39(100)$ \\
\hline 2003 & $4(10.5)$ & $24(63.2)$ & $10(26.3)$ & $38(100)$ \\
\hline
\end{tabular}

Table 3

Results of the mouse test for the evaluation of the sensitivity of $T$. congolense isolates to DA at different doses.

\begin{tabular}{|c|c|c|c|c|c|}
\hline \multirow[t]{2}{*}{ Number of $T$. congolense isolates } & \multirow[t]{2}{*}{ RFLP profile } & \multicolumn{4}{|c|}{ Number of relapsing mice for different doses of DA } \\
\hline & & $1 \mathrm{mg} / \mathrm{kg}$ & $5 \mathrm{mg} / \mathrm{kg}$ & $20 \mathrm{mg} / \mathrm{kg}$ & $40 \mathrm{mg} / \mathrm{kg}$ \\
\hline 22 & $\mathrm{~S}$ or $\mathrm{M}$ & $5 / 5$ & ND & $\leq 1 / 5$ & $0 / 5$ \\
\hline 2 & $\mathrm{R}$ & $5 / 5$ & $\geq 1 / 5$ & $\leq 1 / 5$ & $0 / 5$ \\
\hline 1 & $\mathrm{R}$ & ND & ND & $=6 / 6$ & ND \\
\hline
\end{tabular}

S: Sensitive; M: mixed; R: resistant; ND: not done.

which confirms the presence of heterozygous individuals in the trypanosome populations.

Table 2 summarises the $B c l I-P C R-R F L P$ profiles of all the isolates. The data show that the number of DA sensitive isolates has decreased from $61.5 \%$ in 1996 to $10.5 \%$ in 2003, whereas the DA resistant isolates increased from 12.8 to $63.2 \%$ over the same time period. The association between the date of sampling and the DA-sensitivity of the isolates is highly significant $\left(p=6.014 \times 10^{-7}\right)$ representing a huge increase of the proportion of resistant isolates in the trypanosomes isolated in 2004.

Out of the 77 isolates, 25 were tested in mice. The results (Table 3) show that 22 isolates with either a sensitive or mixed BclI-PCR-RFLP profile can be considered as sensitive to DA because there were less than $20 \%$ relapses at a dose of $20 \mathrm{mg} / \mathrm{kg}$ DA. Two isolates with a resistant $B c l \mathrm{I}-P C R-R F L P$ profile had less than $20 \%$ relapses at $20 \mathrm{mg} / \mathrm{kg}$ DA, but more than $20 \%$ relapses at a dose of $5 \mathrm{mg} / \mathrm{kg}$. This confirms earlier findings that the molecular test might be more sensitive in detecting DA resistance than the mouse test (Delespaux et al., 2006). One isolate representing a resistant $B c l I-P C R$ RFLP profile showed more than $20 \%$ relapses $(100 \%)$ at $20 \mathrm{mg} / \mathrm{kg}$. The results of the tests in mice do not allow differentiating between recessiveness or incomplete dominance as no difference was observed between homozygous sensitive and heterozygous trypanosomes at the doses used, but complete dominance can be excluded. A full range of DA doses between 1 and $20 \mathrm{mg} / \mathrm{kg}$ might allow for the differentiation between the DA sensitivity of homozygous sensitive and heterozygous trypanosome strains. Since these results confirm earlier findings (Delespaux et al., 2006) that there is a good correlation (88.5-91.7\%) between the BclI-PCR$R F L P$ test and the mouse test, the BclI-PCR-RFLP test can be considered as an effective, quick and accurate molecular tool for monitoring DA-resistance. The usefulness of such a tool was already demonstrated in a large-scale study on trypanocidal drug resistance in Cameroon (Mamoudou et al., 2008).
Considering the magnitude of the observed increase in DA-resistance in the study area over a seven-year period, it seems unlikely that the spread in the trypanosome population of the point mutation within the TcoATl gene could be the result of point mutations that occur independently due to increased drug pressure. Genetic exchange has been demonstrated in Trypanosoma brucei (Jenni et al., 1986; Tait and Turner, 1990; Gibson and Whittington, 1993; Gibson and Stevens, 1999; Tait et al., 2007). Although genetic exchange has not been demonstrated in T. congolense, it is highly likely that it occurs similarly to $T$. brucei. It may explain the observed rapid development of DA-resistance in the trypanosome population of the study area. This is especially so since trypanocidal drug use, with a treatment frequency of 1.25 DA treatments/animal/year (Van den Bossche et al., 2000), and thus trypanocidal drug pressure is not very high and has not changed over the years.

The results of this study clearly demonstrate that DAresistance is developing very fast in the Eastern Province. The factors contributing to this rapid development need further investigation and will contribute substantially to a better understanding of the epidemiology of trypanocidal drug resistance. Since a high prevalence of resistance to ISM has already been demonstrated in the study area (Sinyangwe et al., 2004), the findings of the present study underline the need for alternative methods to control the disease such as vector control using, for example, insecticide-impregnated targets or insecticide-treated cattle.

\section{References}

Delespaux, V., Ayral, F., Geysen, D., Geerts, S., 2003. PCR-RFLP using Ssu-rDNA amplification: applicability for the diagnosis of mixed infections with different trypanosome species in cattle. Vet. Parasitol. 117, 185-193.

Delespaux, V., Chitanga, S., Geysen, D., Goethals, A., Van den Bossche, P., Geerts, S., 2006. SSCP analysis of the P2 purine transporter TcoAT1 gene of Trypanosoma congolense leads to a simple PCR-RFLP test allowing 
the rapid identification of diminazene resistant stocks. Acta Trop. 100, 96-102.

Delespaux, V., Geysen, D., Van den Bossche, P., Geerts, S., 2008. Molecular tools for the rapid detection of drug resistance in animal trypanosomes. Trends Parasitol. 24, 236-242.

Eisler, M.C., Brandt, J., Bauer, B., Clausen, P.H., Delespaux, V., Holmes, P.H., Ilemobade, A., Machila, N., Mbwambo, H., McDermott, J., Mehlitz, D., Murilla, G., Ndung'u, J.M., Peregrine, A.S., Sidibe, I., Sinyangwe, L., Geerts, S., 2001. Standardised tests in mice and cattle for the detection of drug resistance in tsetse-transmitted trypanosomes of African domestic cattle. Vet. Parasitol. 97, 171-182.

Geysen, D., Delespaux, V., Geerts, S., 2003. PCR-RFLP using Ssu-rDNA amplification as an easy method for species-specific diagnosis of Trypanosoma species in cattle. Vet. Parasitol. 110, 171-180.

Gibson, W., Stevens, J., 1999. Genetic exchange in the trypanosomatidae. Adv. Parasitol. 43, 1-46.

Gibson, W., Whittington, H., 1993. Genetic exchange in Trypanosoma brucei: selection of hybrid trypanosomes by introduction of genes conferring drug resistance. Mol. Biochem. Parasitol. 60, 19-26.

Herbert, W.J., Lumsden, W.H.R., 1976. Trypanosoma brucei: a rapid "matching" method for estimating the host's parasitaemia. Exp. Parasitol. 40, 427-431.

Jenni, L., Marti, S., Schweizer, J., Betschart, B., Lepage, R.W.F., Wells, J.M., Tait, A., Paindavoine, P., Pays, E., Steinert, M., 1986. Hybrid formation between African trypanosomes during cyclical transmission. Nature 322, 173-175.

Mamoudou, A., Delespaux, V., Chepnda, V., Hachimou, Z., Andrikaye, J.P., Zoli, A., Geerts, S., 2008. Assessment of the occurrence of trypanocidal drug resistance in trypanosomes of naturally infected cattle in the Adamaoua region of Cameroon using the standard mouse test and molecular tools. Acta Trop. 106, 115-118.

Masumu, J., Geysen, D., Vansnick, E., Geerts, S., Van den Bossche, R., 2006. A modified AFLP for Trypanosoma congolense isolate characterisation. J. Biotechnol. 125, 22-26.
Mattioli, R.C., Feldmann, G., Hendrickx, W., Wint, J., Jannin, J., Slingenbergh, J., 2004. Tsetse and trypanosomiasis intervention policies supporting sustainable animal-agricultural development. Food Agric. Environ. Food Agric. Environ., 310-314.

Murray, M., Murray, P.K., Mcintyre, W.I.M., 1977. Improved parasitological technique for diagnosis of African trypanosomiasis. T. Roy. Soc. Trop. Med. H. 71, 325-326.

Sambrook, J., Fritsch, E.F., Maniatis, T., 1989. Molecular Cloning: A Laboratory Manual. Cold Spring Arbor, New York.

Simukoko, H., Marcotty, T., Phiri, I., Geysen, D., Vercruysse, J., Van den Bossche, P., 2007. The comparative role of cattle, goats and pigs in the epidemiology of livestock trypanosomiasis on the plateau of Eastern Zambia. Vet. Parasitol. 147, 231-238.

Sinyangwe, L., Delespaux, V., Brandt, J., Geerts, S., Mubanga, J., Machila, N., Holmes, P.H., Eisler, M.C., 2004. Trypanocidal drug resistance in Eastern province of Zambia. Vet. Parasitol. 119, 125-135.

Smith, C.J., Levine, R.F., Mansfield, J.M., 1982. Cloning of African trypanosomes in mice immunosuppressed by cyclophosphamide treatment. Am. J. Trop. Med. Hyg. 31, 1098-1102.

Swallow, B.M., 2000. Impacts of trypanosomosis on African agriculture. PAAT Technical Scientific Series 2. FAO, Rome, Italy.

Tait, A., Turner, C.M.R., 1990. Genetic exchange in Trypanosoma brucei. Parasitol. Today 6, 70-75.

Tait, A., MacLeod, A., Tweedie, A., Masiga, D., Turner, C.M.R., 2007. Genetic exchange in Trypanosoma brucei: evidence for mating prior to metacyclic stage development. Mol. Biochem. Parasitol. 151, 133-136.

Van den Bossche, P., Staak, C., 1997. The importance of cattle as a food source for Glossina morsitans morsitans in Katete district, Eastern Province, Zambia. Acta Trop. 65, 105-109.

Van den Bossche, P., Doran, M., Connor, R.J., 2000. An analysis of trypanocidal drug use in the Eastern Province of Zambia. Acta Trop. 75, 247-258.

Weisstein, E.W., 2008. MathWorld: A Wolfram Web Resource. http://mathworld.wolfram.com/FishersExactTest.html. 